\title{
The World Health Organization in Global Health Law
}

\author{
Benjamin Mason Meier, \\ Allyn Taylor, Mark \\ Eccleston-Turner, Roojin \\ Habibi, Sharifah Sekalala, \\ and Lawrence O. Gostin
}

International collaboration is crucial to the COVID-19 response. In realizing global solidarity, the World Health Organization (WHO) has sought to bring the world together to respond to a shared threat. This collaboration has required global health law, with WHO long developing regulations to bind states under international law. As the international community faces its greatest modern test in the COVID-19 pandemic, WHO has confronted unprecedented challenges, with states neglecting international legal commitments in the pursuit of nationalist disease responses. Given the limitations of international law in the COVID-19 response, it will be crucial to reform global health law, with sweeping implications for the future of WHO governance.

This column seeks to examine the central importance of WHO in developing and implementing global health law. Recognizing that global health law requires global governance, the column begins by situating WHO's role at the forefront of global health governance. WHO's leadership in global governance for health is supported by an expansive mandate to serve as a forum for the codification of international law, which WHO has exercised sporadically through the evolving development of the International Health Regulations (IHR). Yet, where the IHR have proven incommensurate to the COVID-19 challenge, WHO now finds itself at a crossroads, with this column considering a range of reforms that may be proposed in the years to come.

\section{Global Health Law Depends on Global Health Governance}

In coordinating the global community to address common health threats, WHO is intended to be central in global health governance, binding states together through the development and implementation of international law to prevent disease and promote health.

Global health law looks beyond the efforts of individual nations to encompass the larger set of determinants that structure public health in a globalizing world. With globalization connecting societies in shared vulnerability, these forces have exposed the limitations of domestic law in addressing global determinants of health. ${ }^{1}$ Global health law recognizes that all nations face common public health threats, requiring collective global action to realize global health equity. ${ }^{2}$ Providing an international legal foundation for global health governance, global health law supports global institutions to negotiate a shared vision of global health, coordinate with organizations across sectors, and align national laws to advance public health in a globalizing world. ${ }^{3}$ In uniting states under binding legal obligations and bringing together state and non-state actors

Benjamin Mason Meier, J.D., LL.M., Ph.D., is an Associate Professor of Global Health Policy at the University of North Carolina at Chapel Hill, a Scholar at the O'Neill Institute for National and Global Health Law, and the Chair of the Global Health Law Consortium. Allyn Taylor, J.D., LL.M., J.S.D., is an Affiliate Professor of Law at the University of Washington. Mark Eccleston-Turner, LL.B, LL.M., Ph.D, is a Lecturer of Law at the University of Keele. Roojin Habibi, J.D., M.Sc., is the Research Coordinator of the Global Health Law Consortium, and Doctoral Candidate at Osgoode Hall Law School, York University. Sharifah Sekalala LL.B., LL.M., Ph.D., is an Associate Professor of Law at the University of Warwick. Lawrence O. Gostin, J.D., LL.D. (Hon.), is University Professor at Georgetown University, the Founding Linda D. E' Timothy J. O'Neill Professor of Global Health Law at Georgetown University Law Center, and the Director of the World Health Organization Collaborating Center on National and Global Health Law. 
under "soft law" commitments, global health law could not exist without global health governance.

Global governance has become crucial in developing legal norms and implementing those norms across nations through global institutions. Through an extensive body of international organizations, states have come together to respond to global challenges, working to create coordinated responses to rising threats. Operating under global health law,
WHO emerged in the aftermath of World War II, with nations seeking to create centralized authority to coordinate international responses to rising health threats. ${ }^{8}$ With the 1945 Charter of the United Nations calling for the creation of a United Nations (UN) specialized agency for health, nations rapidly established this new international organization, subsuming within WHO all of the responsibilities of the Health Organization of the League of Nations, the Office

\section{It will be crucial to reform global health law to prepare for future global health challenges, but WHO member states find themselves at a crossroads in their reforms: accept the divisive nationalist responses which have characterized the response to COVID-19 or recommit to international cooperation through global health} governance.

these governance institutions can set norms for global action, developing consensus on shared goals for global health. ${ }^{4}$ International organizations thereby serve as the primary governance institutions for the creation of international legal frameworks - including both binding and nonbinding agreements - which, in turn, shape national responses as states implement international legal obligations. Through the development of international law, these global governance institutions can develop global health law to frame the obligations of states. ${ }^{5}$ These institutions provide a basis for member states to negotiate international legal agreements, facilitate international accountability, and shape global health norms. ${ }^{6}$ With globalization exacerbating the risks of disease and increasing the need for multilateral cooperation, global health governance has become increasingly crucial in developing international law to unite states against infectious disease threats. ${ }^{7}$

In responding to globalized disease threats, WHO lies at the forefront of global health governance.
International d'Hygiene Publique (OIHP), and the Health Division of the United Nations Relief and Rehabilitation Administration (UNRRA) ${ }^{9}$ The 1946 WHO Constitution looked to create a healthier world out of the horrors of World War II. Declaring "the highest attainable standard of health" to be a fundamental right of every human being, the WHO Constitution provided WHO with expansive international legal authority to codify international treaties, regulations, and recommendations to address any matter of public health importance.

\section{The World Health Organization Advances Global Health Law Through Global Health Governance}

Among international organizations, WHO has the widest ranging legal authority to address global public health concerns. As the UN specialized agency with a constitutional mandate to act as the "directing and coordinating authority" on international health work, WHO has broad legal authority to serve as a forum for international health lawmaking. ${ }^{10}$
Article 19 of the WHO Constitution specifies that the World Health Assembly, WHO's legislative body composed of all of its member states, "shall have the authority to adopt conventions or agreements with respect to any matter within the competence of the Organization."11 With the legal authority to serve as a platform for conventions and agreements that potentially address all aspects of public health, the WHO Constitution also confers authority on WHO to develop non-binding recommendations under Article 23 and regulations under Article 21 of its Constitution. Although WHO has until recently neglected the development of international law to address the full range of global health threats, ${ }^{12}$ it has always maintained its principal role for developing international legal cooperation in infectious disease control. ${ }^{13}$

Upon its establishment in 1948 , WHO inherited from predecessor organizations the managerial responsibility over the international legal regime securing multilateral cooperation to control the international spread of disease. These international regulations were first adopted by the World Health Assembly in 1951, and have been subject to a number of revisions over the years, generally resulting from global improvements in epidemiological knowledge and control of epidemic diseases. ${ }^{14}$ Last revised in 2005, the current IHR are binding on 196 state parties, making it one of the most widely subscribed to binding agreements under the UN system and forming the contemporary legal foundation for international disease control.

The IHR codify WHO's legal authority to lead international efforts "to prevent, protect against, control and provide a public health response to the international spread of disease." ${ }^{15}$ Adopted under Article 21 of the WHO Constitution, the IHR bind states parties pursuant to a unique contracting-out procedure that is designed to simplify and expedite the lawmaking process for infectious disease control. Regulations under Article 21 come into force automatically for all WHO member states, 
except for those states that explicitly notify WHO's Director-General of any rejection or reservations, obligating states under this international legal framework to reform domestic public health policy to comport with IHR provisions. ${ }^{16}$ Framing responses to protect national security and international trade, the IHR have been employed over the past fifteen years to respond to six public health emergencies of international concern, including COVID-19. ${ }^{17}$ While the IHR outline the key steps in assessing and responding to public health threats, the ongoing COVID-19 pandemic is a stark reminder of the limitations of global health law in overcoming global health emergencies.

\section{WHO Governance in the Legal Response to COVID-19}

Limiting WHO's leadership in the global governance response to the COVID-19 pandemic, key provisions of the IHR proved insufficient from the outset of the SARS-CoV-2 outbreak in Wuhan. Where the IHR calls for transparency and the rapid flow of information about public health risks from local authorities to WHO, China's official WHO notification drew international criticism for repressing early warnings from non-governmental sources. ${ }^{18}$ Further, the declaration of a Public Health Emergency of International Concern (PHEIC) - a role reserved for the WHO DirectorGeneral - was deliberated extensively behind closed doors by a committee of experts, delaying the WHO PHEIC declaration. ${ }^{19}$ Once declared, fear and uncertainty tinged nationalist responses to the novel coronavirus, as states neglected WHO guidance, violated human rights, and imposed travel bans that fractured an interconnected world. ${ }^{20}$ Despite WHO efforts to rally global solidarity in the pandemic response, states have neglected the long unrealized promise of international assistance and collaboration to build resilient public health capacities throughout the world. Nationalism is now impeding the distribution of a prospective vaccine, where states are undermining a human rights imperative to ensure equitable vaccine access. ${ }^{21}$ These limi- tations of international law raise questions about the adequacy of WHO governance under the IHR to resolve the complex multisectoral challenges presented by the present health crisis.

While the IHR aim to support states in preventing, detecting, and responding to infectious disease, they appear inadequate in the pandemic response, with insufficient mechanisms to ensure a coordinated approach across WHO member states. ${ }^{22}$ Rather than looking to the IHR, WHO has primarily worked through non-binding mechanisms in taking an active governance role in key aspects of the response to the pandemic, drawing on its "soft law" authorities in facilitating research and development of new therapeutics and vaccines against COVID-19 and trying to ensure universal and equitable access. ${ }^{23}$ However, these governance actions, which remain vital to the response to COVID-19, have not been grounded in the IHR, as WHO's "legal authority ... in the response to COVID-19 stems not from the International Health Regulations, but the Constitution of the World Health Organization." 24 Grounding key aspects of the response to a health emergency in the governance powers of the Constitution, rather than the binding legal authorities of the IHR, gives rise to concerns regarding the effectiveness of global health law.

Following from the limitations of the COVID-19 response, it will be crucial to examine how to address future global health threats more effectively under global health law. Central to this issue is the potential reform of the IHR, and there are already discussions underway to "reimagine the IHR as an instrument that will compel global solidarity and national action against the threat of emerging and re-emerging pathogens." ${ }^{25}$ Such calls for reform are likely to intensify, and shift into the World Health Assembly, where meaningful international debate can occur on the role of global health law in responding to future health emergencies through global health governance. Seeing this crisis as a catalyst for sweeping change, some scholars have called for a "Joint UN Programme on Infec- tious Diseases," an expanded governance mechanism to foster multisectoral collaboration across the full range of actors (within and outside of the UN system, including WHO) that are implicated in the prevention and response to future pandemics. ${ }^{26}$

\section{Conclusion}

It will be crucial to reform global health law to prepare for future global health challenges, but WHO member states find themselves at a crossroads in their reforms: accept the divisive nationalist policies which have characterized the response to COVID-19 or recommit to international cooperation through global health governance. In preparing for the next health emergency, the latter path is clearly more politically challenging, as such global solidarity requires member states to relinquish sovereignty over certain aspects of health policy and greatly enhance the funding available for WHO in the pandemic response. While the former path is both less contentious and less expensive, allowing states to prioritize national interests, it comes at the risk of exacerbating and prolonging future health emergencies. This is not a decision for WHO, but for its member states, yet these political decisions regarding global health law will shape the future of global health governance.

Acknowledgments

In developing this column, the authors are grateful to Anahita Gupta for her thoughtful research assistance on WHO legal authorities.

Note

The authors are members of the Global Health Law Consortium, a collaborative interdisciplinary research initiative focused on advancing global health law. Learn more about the Consortium and its work at globalhealthlaw.org.

\section{References}

1. A. Taylor, "Making the World Health Organization Work: A Legal Framework for Universal Access to the Conditions for Health," American Journal of Law छ Medicine 18, no. 4 (1992): 301-346.

2. $\quad$ L. O. Gostin, Global Health Law (Cambridge, MA: Harvard University Press, 2014).

3. L. O. Gostin and B. M. Meier, "Introducing Global Health Law," Journal 
of Law, Medicine छ Ethics 47, no. 2 (2020): 788-793.

4. J. Klabbers, Advanced Introduction to the Law of International Organizations (Cheltenham, UK: Edward Elgar, 2015).

5. B. Toebes, "Global Health Law: Defining the Field," in Research Handbook on Global Health Law, G. L. Burci and B. Toebes, eds. (Cheltenham, UK: Edward Elgar, 2018), at 2-22.

6. L. O. Gostin and B. M. Meier, "Framing Human Rights in Global Health Governance," in Human Rights in Global Health, B. Mason Meier and L. O. Gostin, eds. (New York: Oxford University Press, 2018): 63-68.

7. A. Taylor, "Governing the Globalization of Global Health," Journal of Law, Medicine छ Ethics 32, no. 3 (2004): 500-508.

8. J. A. Doull, "Nations United for Health," in Public Health in the World Today, J. Stevens Simmons, ed. (Cambridge, MA: Harvard University Press, 1949): 317-332.

9. M. Cueto, T. Brown and E. Fee, The World Health Organization: A History (Cambridge, UK: Cambridge University Press, 2018).

10. A. Taylor, Health: The Oxford Handbook of United Nations Treaties (New York: Oxford University Press, 2019).

11. WHO, Constitution, Article 19 (1946).

12. Taylor, supra note 1.

13. D. P. Fidler, International Law and Infectious Diseases (Oxford: Clarendon Press, 1999).

14. Gostin and Meier, supra note 3.
15. International Health Regulations, 2005, article 2, available at $<$ https://www.who.int/ihr/publications/9789241596664/en/> (last visited November 12, 2020).

16. D. P. Fidler and L. O. Gostin, "The New International Health Regulations: An Historic Development for International Law and Public Health," Journal of Law, Medicine Eं Ethics 34, no. 1 (2006): 85-94.

17. L. O. Gostin, R. Habibi and B. M. Meier, "Has Global Health Law Risen to Meet the COVID-19 Challenge? Revisiting the International Health Regulations to Prepare for Future Threats," Journal of Law, Medicine $\Xi$ Ethics 48, no. 2 (2020): 376-381.

18. E. Petersen et al., "Li Wenliang, A Face to the Frontline Healthcare Worker: The First Doctor to Notify the Emergence of the SARS-CoV-2, (COVID19), Outbreak," International Journal of Infectious Diseases 93 (2020): 205-207.

19. M. Eccleston-Turner, "COVID-19 Symposium: The Declaration of a Public Health Emergency of International Concern in International Law," Opinio Juris (2020), available at <http:// opiniojuris.org/2020/03/31/covid19-symposium-the-declaration-of-apublic-health-emergency-of-international-concern-in-international-law/> (last visited October 30, 2020)

20. R. Habibi et al., "Do Not Violate the International Health Regulations During the COVID-19 Outbreak," Lancet 395, no. 10225 (2020): 664-666; B.
M. Meier, R. Habibi, and Y. T. Yang, "Travel Restrictions Violate International Law," Science 367, no. 6485 (2020): 1436-1436

21. L. O. Gostin, S. Abdool Karim, and B. M. Meier, "Facilitating Access to a COVID-19 Vaccine through Global Health Law," Journal of Law, Medicine छீ Ethics 48, no. 3 (2020): 622-626.

22. A. L. Taylor et al., "Solidarity in the Wake of COVID-19: Reimagining the International Health Regulations," The Lancet 396, no. 10244 (2020): 82-83.

23. S. Sekalala, Soft Law and Global Health Problems: Lessons from Responses to HIV/AIDS, Malaria and Tuberculosis (Cambridge, UK: Cambridge University Press, 2017).

24. G. Luca Burci and M. Eccleston-Turner, "Preparing for the Next Pandemic: The International Health Regulations and World Health Organization during COVID-19" Yearbook of International Disaster Law 2, no. 1 (2020): 1-28.

25. Taylor et al., supra note 22.

26. A. L Taylor and R. Habibi, "The Collapse of Global Cooperation under the WHO International Health Regulations at the Outset of COVID-19: Sculpting the Future of Global Health Governance," ASIL Insights 24, no. 15 (2020): 15 . 